\title{
A Rare Case of Inflammatory Myofibroblastic Tumor of the Prostate and Review of the Literature
}

\author{
MIN SEOK KIM ${ }^{1}$ and SUNG-CHUL LIM ${ }^{2}$ \\ ${ }^{1}$ Department of Urology, College of Medicine, Chosun University, Gwangju, Republic of Korea; \\ ${ }^{2}$ Department of Pathology, College of Medicine, Chosun University, Gwangju, Republic of Korea
}

\begin{abstract}
Background: Inflammatory myofibroblastic tumor (IMT) is a rare type of soft-tissue neoplasm. IMT of the urinary tract is more common in the bladder and kidneys. Prostatic IMT is extremely rare. Case Report: We present a rare case of IMT of the prostate and a literature review on this condition. The patient was a 72-year-old man who presented with urinary symptoms. Transrectal needle biopsy of the prostate revealed prostatic adenocarcinoma with nodular hyperplasia. Radical prostatectomy revealed IMT without residual adenocarcinoma. On immunohistochemical examination, the tumor cells showed positive immunoreactivity for $\alpha$-smooth muscle actin, CD10, CD34, and desmin but negative immunoreactivities for anaplastic lymphoma kinase (ALK), receptor tyrosine kinase (c-KIT), and S-100 protein. The patient underwent regular follow-up examination. No recurrence was observed 4 months after the diagnosis. Conclusion: This was a case of IMT arising in the prostate. Pathologists should be aware of such an entity whenever they see spindle-cell lesions in the transrectal needle biopsy of the prostate.
\end{abstract}

Spindle-cell lesions that resemble nodular fasciitis and occur mainly in soft tissues occur in the urinary tract on rare occasions and are commonly observed in the kidney and urinary bladder (1-4). As similar lesions occur largely in relation to injury during prior procedures, they have also been referred under different titles, including "reactive pseudosarcomatous response", "inflammatory pseudotumor", "pseudosarcomatous fibromyxoid tumor", "pseudosarcomatous lesion", "inflammatory myofibroblastic tumor (IMT)". Since

This article is freely accessible online.

Correspondence to: Sung-Chul Lim, MD, Ph.D., Department of Pathology Chosun University Hospital, 365, Pilmoon-daero, Donggu, Gwangju, Republic of Korea. Tel: +82 622306343, Fax: +82 622265860, Mobile: +82 1092676343, e-mail: sclim@ chosun.ac.kr

Key Words: Inflammatory myofibroblastic tumor, prostate, ALK, immunohistochemistry. the discovery of the alteration of anaplastic lymphoma kinase $(A L K)$ gene in such bladder lesions, the lesions are treated as the result of neoplastic rather than reactive processes, and the name IMT has been preferred (4-6). Prostate IMT is rare, and only nine cases have been recorded in the English literature since it was first reported in 1984 as an atypical fibromyxoid tumor (7-14).

The purpose of this study was to examine the clinical and pathological characteristics of prostate IMT, and particularly to identify previous history of injury and the prognostic differences of prostate IMT in relation to ALK expression, by reviewing case experiences and the literature.

\section{Case Report}

A 71-year-old man was admitted to our hospital with liver abscess, and percutaneous abdominal drainage was performed. The man was discharged after 18 days of treatment, as his symptoms improved. The patient had been receiving outpatient care for diabetes and hypertension for many years. Computed tomography (CT) performed on admission revealed a cystic lesion $1.6 \mathrm{~cm}$ in diameter in the right prostate, which was suspected to be an abscess (Figure 1A). The serum prostate-specific antigen (PSA) level at the time was $15.3 \mathrm{ng} / \mathrm{ml}$. Transrectal needle biopsy of the prostate 2 weeks after discharge revealed nodular hyperplasia and atypical small acinar proliferation from the single core. Even upon retrospective re-examination of the entire biopsy slide, no specific abnormalities, such as spindle-cell proliferation, were identified.

Transrectal needle biopsy of the prostate 11 months later showed prostatic adenocarcinoma with a Gleason score of 6 $(3+3)$ in a single core $(\# 6)$, and no specific abnormalities such as spindle-cell proliferation other than nodular hyperplasia were found from the retrospective reexamination of the entire biopsy slide. The serum PSA level at this time was $3.92 \mathrm{ng} / \mathrm{ml}$. Therefore, prostate magnetic resonance imaging (MRI) was performed, and an area of low signal intensity with a $1.2-\mathrm{cm}$ diameter and low signal intensity on $\mathrm{T}_{2}$-weighted imaging in the anterior peripheral 
zone of the left prostatic gland, which was assumed to be a prostatic cancer (Figure 1B), was observed. In addition, an area of low signal intensity, $3.2 \mathrm{~cm}$ in diameter, with low signal intensity on $\mathrm{T}_{2}$-weighted imaging in the posterior transitional zone of both prostatic glands (Figure 1C) was observed. As we decided there was no extra-prostatic tumor extension, hormone therapy (bicalutamide; Calutami, 50 $\mathrm{mg}$ /day) was conducted for 5 weeks. Radical prostatectomy was performed after this therapy, and the prostate had enlarged to approximately $120 \mathrm{~g}$. To accurately observe and evaluate the tumor, mapping was performed on the prostate. No residual prostatic adenocarcinoma was observed under microscopy but a mass was found of $5.2 \times 3.7 \times 3.2 \mathrm{~cm}$, excluding the upper 5 -mm thickness on the apex of the prostate and the 3-mm thickness on the bottom base of the prostate. The mass was present throughout almost the entire axis of the prostate and was observed because it was well circumscribed from the surrounding nodular hyperplastic lesions (Figure 2). Intratumoral lymphocytes were scattered or formed aggregations, and were infiltrating, and occasionally resembled lymphoid follicles. Spindle cells were observed with abundant vessels in the loose edematous stroma or were aggregated more compactly; necrosis, cellular atypia, and mitosis were not found (Figure 2B and C). On immunohistochemical examination, spindle tumor cells were positive for $\alpha$-smooth muscle actin, CD10, CD34, and desmin, and negative for ALK, receptor tyrosine kinase (c-KIT), and S-100 protein (Figure 3). On the basis of the clinicopathological findings, we concluded that this tumor represented IMT arising in the prostate. At the 4-month follow-up, the patient was well with no evidence of disease.

\section{Discussion}

IMT is a rare disease that occurs mainly in soft tissues but is also a borderline tumor that occurs in prostate, and its exact etiology is still unknown. It was considered to occur as an abnormal reparative response due to traumatic or surgical tissue injury, or viral (Epstein-Barr virus, herpes virus 8$)$ and bacterial infection $(15,16)$ but ALK-positive findings with a common 2 p23 rearrangement was observed in $40-60 \%$ of IMTs, which supports the opinion that it is a true neoplasm (17).

Upon examination of the cases of prostatic IMT reported in the English literature (7-14), it was found to occur in various age groups (21-83 years old) but commonly in the elderly (mean age $=60.8$ years), and the chief complaint of patients was urinary obstruction symptoms, which were occasionally accompanied by hematuria or fever. In some patients there was difficulty in accurately assessing the size of the tumor because although the tumor was diagnosed through transurethral resection of the prostate (TUR-P) and transperineal biopsy, the diameters ranged from 1.2 to $6.5 \mathrm{~cm}$.
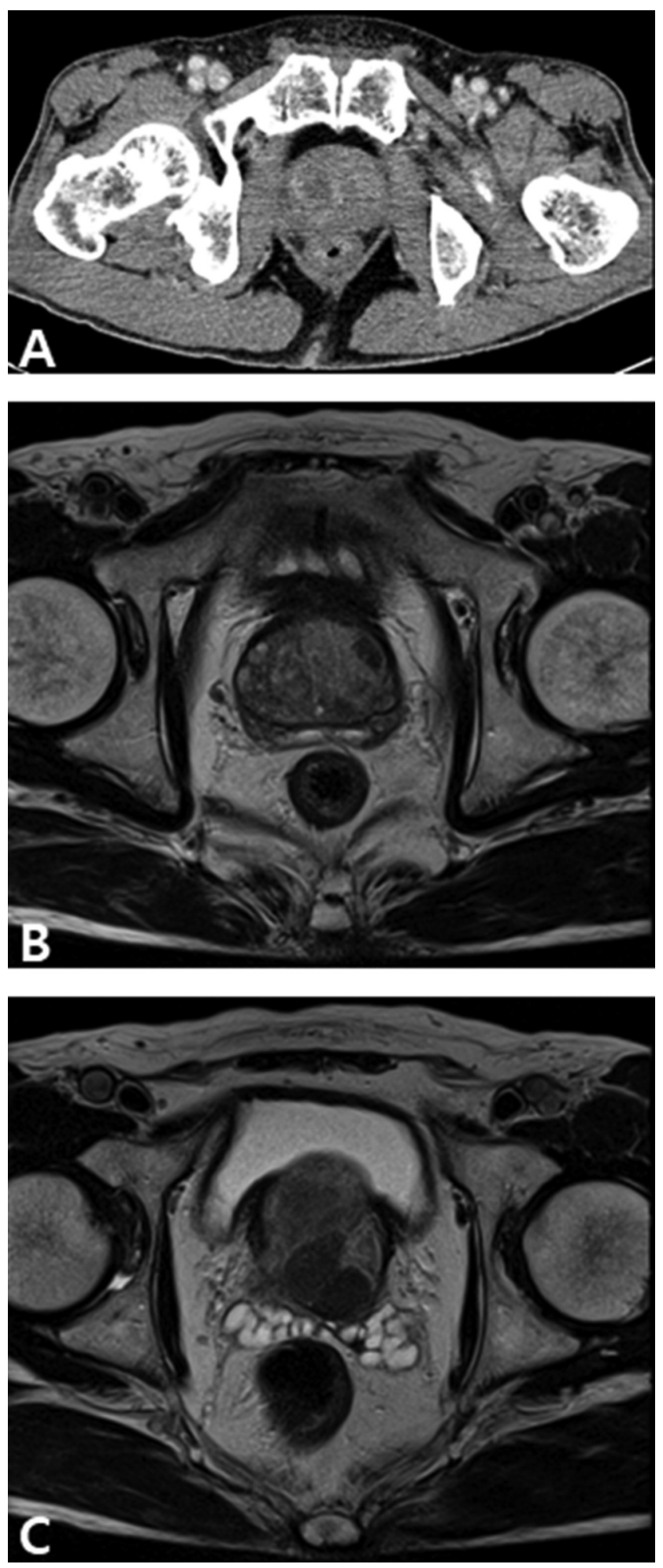

Figure 1. Computed tomographic findings showed a 1.6-cm cystic lesion that suggested an abscess in the right prostate (A). Magnetic resonance imaging showed a $1.2 \mathrm{-cm}$ low signal intensity area in the anterior peripheral zone of the left prostatic gland $(B)$ and 3.2-cm low signal intensity area in the posterior transitional zone of both prostatic glands $(C)$. 


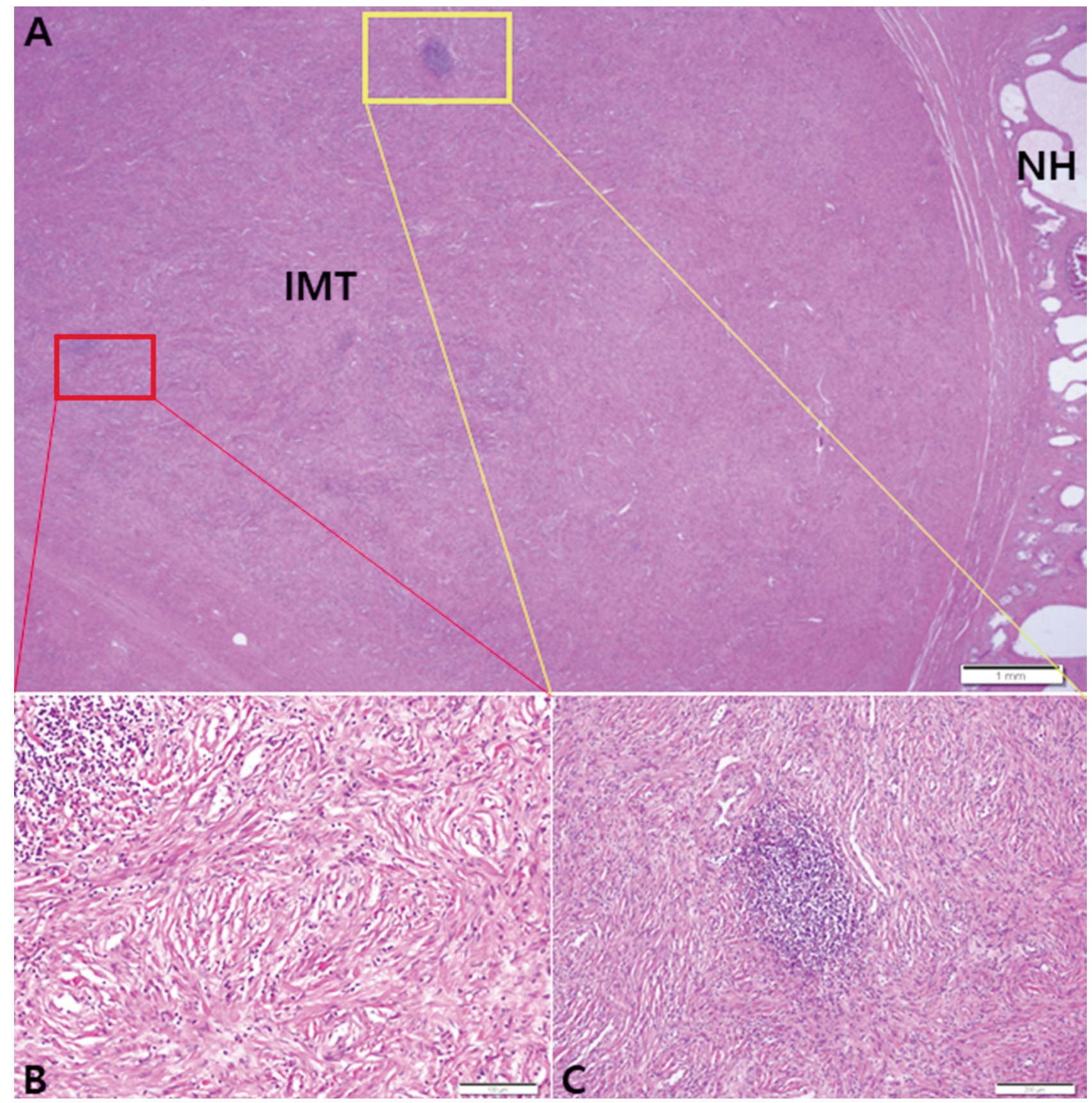

Figure 2. Histopathological findings from the radical prostatectomy sample. A: A well-circumscribed inflammatory myofibroblastic tumor (IMT) and surrounding nodular hyperplasia $(\mathrm{NH})$ were identified. A lymphoid follicle-like structure can be seen (yellow box). B: High-power view of the area in A, showing alternating dense and loose edematous stromata with vascular channels and inflammatory cells. C: High-power view of the lymphoid follicle-like structure in A. Compact arrangement of spindle cells with vascular channels, sprinkled lymphocytes, and follicle-like lymphoid aggregates in the stroma can be seen.

Previous injury or suspicious findings were present in: five out of 10 cases with a 10-month (12) or 4-year TUR-P history (14); those with a 4-year history of irradiation to the prostate and transurethral resection of bladder tumor 1 month earlier (11); those with a 2.5-year history of infarction-associated lesions from TUR-P (8); and in the present case, with suspected prostatic abscess findings 13 months earlier. Prior to the confirmation of the IMT diagnosis, prostatic IMT was diagnosed as nodular hyperplasia in most biopsy examinations and were diagnosed as low-grade sarcoma (7). Other cases of 

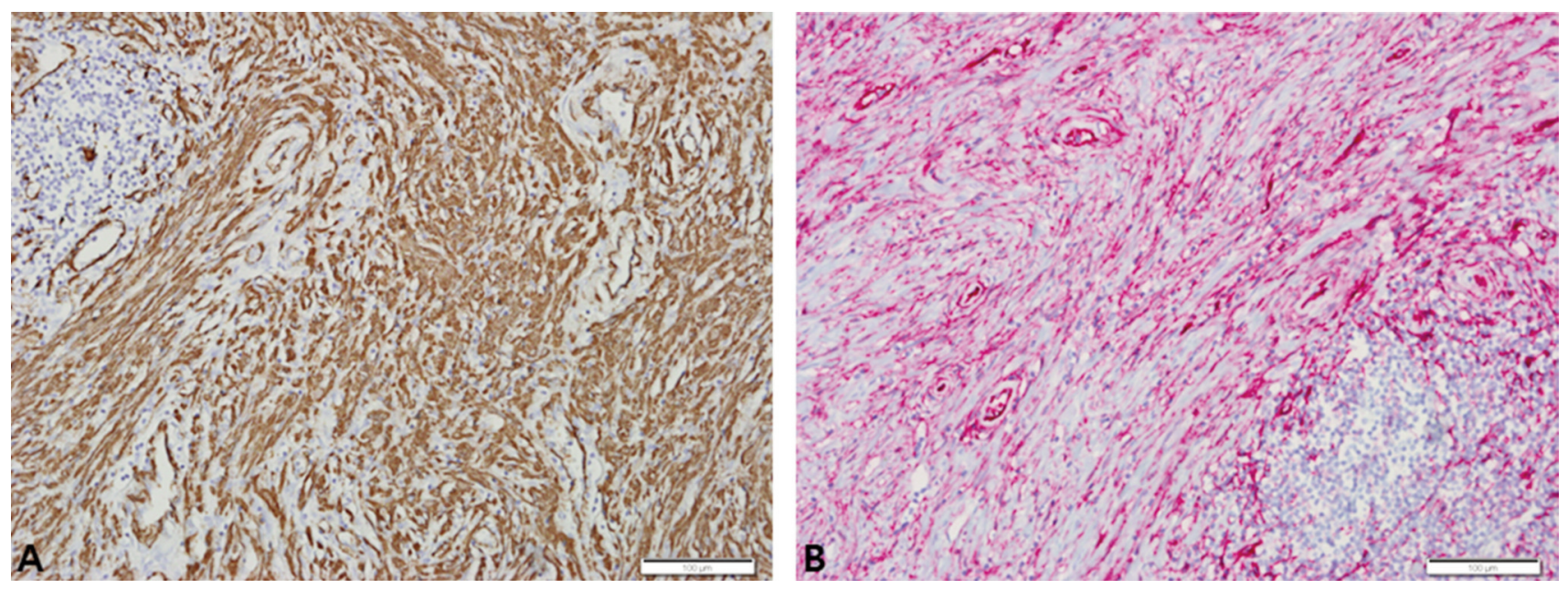

Figure 3. Immunohistochemical staining for $\alpha$-smooth muscle actin and CD34. The spindle tumor cells show strong immunoreactivity for $\alpha$-smooth muscle actin $(A)$ and $C D 34(B)$.

Table I. Summary of inflammatory myofibroblastic tumor of the prostate in the literature.

\begin{tabular}{|c|c|c|c|c|c|c|c|c|c|c|}
\hline No. & $\begin{array}{l}\text { Author, year } \\
\quad \text { (Ref) }\end{array}$ & $\begin{array}{l}\text { Age, } \\
\text { years }\end{array}$ & Symptoms & Site & $\begin{array}{l}\text { Specimen, } \\
\mathrm{cm}\end{array}$ & Immunohistochemistry & Biopsy & $\begin{array}{l}\text { Follow-up, } \\
\text { (months) }\end{array}$ & Final & Remarks \\
\hline 1 & $\begin{array}{c}\text { Hafiz et al., } \\
1984(7)\end{array}$ & 56 & UO & $\begin{array}{l}\text { Lt. lateral } \\
\text { lobe }\end{array}$ & $\begin{array}{c}\mathrm{CP} \\
(3 \times 1.5)\end{array}$ & $\begin{array}{l}\text {-: for myoglobin, } \\
\text { S-100 }\end{array}$ & $\begin{array}{l}\text { L/G LMS } \\
\text { or RMS }\end{array}$ & NED (18) & AFMT & - \\
\hline 2 & $\begin{array}{l}\text { Young \& Scully, } \\
1987 \text { (8) }\end{array}$ & 51 & $\begin{array}{c}\text { UO } \\
\text { hematuria }\end{array}$ & NA & TUR-P & $\begin{array}{l}\text { +: vimentin } \\
-: \text { desmin, S-100, } \\
\text { myoglobin }\end{array}$ & BPH & $\begin{array}{l}\text { Recurred } \\
\quad(30)\end{array}$ & PSL & $\begin{array}{c}\text { Infarction } \\
\text { in initial } \\
\text { TUR-P sample } \\
\text { AW/9 year }\end{array}$ \\
\hline 3 & $\begin{array}{l}\text { Sahin et al., } \\
\quad 1991 \text { (9) }\end{array}$ & 21 & UO & $\begin{array}{l}\text { Lt. lobe } \\
\quad \mathrm{CZ}\end{array}$ & $\begin{array}{l}\text { TUR-P } \\
(5 \times 5 \times 3 \\
3 \times 3 \times 3)\end{array}$ & $\begin{array}{c}+: \text { actin } \\
\text {-: desmin, S-100, } \\
\text { myoglobin, CK }\end{array}$ & - & Recurred (4) I & PSFMT & AW/4 year \\
\hline 4 & $\begin{array}{l}\text { Jensen } \text { et al., } \\
2003 \text { (10) }\end{array}$ & 43 & $\begin{array}{c}\text { UO } \\
\text { hematuria }\end{array}$ & NA & TUR-P (2) & $\begin{array}{c}\text { +: actin, vimentin, } \\
\text { desmin } \\
-: \text { myoglobin, } S-100, \mathrm{CK}\end{array}$ & - & $\begin{array}{l}\text { Recurred } 5 \\
\text { times }(25)\end{array}$ & PSFMT & $\mathrm{AW} / 2$ year \\
\hline \multirow[t]{2}{*}{5} & $\begin{array}{l}\text { Montgomery et al., } \\
2006 \text { (11) }\end{array}$ & 73 & NA & $B \& P$ & NA (4) & $\begin{array}{l}\text { +: ALK (FISH) } \\
\text {-: ALK, CK (IHC) }\end{array}$ & - & DOOD (9) & IMT & $\begin{array}{l}\text { Prior Hx of } \\
\text { irradiation \& } \\
\text { bladder TUR }\end{array}$ \\
\hline & & 83 & NA & $B \& P$ & $\begin{array}{l}\mathrm{NA} \\
(1.2)\end{array}$ & $\begin{array}{c}\text { +: CK } \\
\text {-: ALK (FISH, IHC) }\end{array}$ & - & NA & IMT & - \\
\hline 6 & $\begin{array}{l}\text { Zhang et al., } \\
2012 \text { (12) }\end{array}$ & 62 & UO & Rt. lobe & TUR-P & $\begin{array}{c}\text { +: desmin, c-kit } \\
\text {-: S-100, CD34, dog-1 }\end{array}$ & $\mathrm{BPH}^{\dagger}$ & $\begin{array}{c}\text { Recurred as } \\
\text { bladder IMT (6) }\end{array}$ & IMT & NED/2 year \\
\hline 7 & $\begin{array}{l}\text { Liu et al., } \\
2013(13)\end{array}$ & 80 & UO & NA & $\operatorname{SPP}(6.5 \times 5.5)$ & $\begin{array}{l}\text { +: actin, vimentin, } \\
\quad \text { desmin } \\
\text {-: c-kit, S-100, CD34 }\end{array}$ & BPH & NED (12) & IMT & $\begin{array}{l}\text { Metastatic IMT } \\
\text { DOD } 30 \text { months } \\
\text { after SPP }\end{array}$ \\
\hline 8 & $\begin{array}{l}\text { Zeng et al., } \\
2018 \text { (14) }\end{array}$ & 67 & $\begin{array}{l}\text { UO } \\
\text { fever }\end{array}$ & NA & ТРВ & $\begin{array}{c}\text { +: actin, vimentin, } \\
\text { desmin, calponin } \\
\text {-: ALK, c-kit, } \\
\text { CD10, S-100 }\end{array}$ & $\mathrm{BPH}^{\ddagger}$ & NED (24) & IMT & - \\
\hline 9 & $\begin{array}{l}\text { Present case, } \\
\quad 2020\end{array}$ & 72 & UO & Both lobes & $\mathrm{RP}(5.2)$ & $\begin{array}{c}\text { +: actin, CD10, } \\
\text { CD34, desmin } \\
-: \text { ALK, c-kit, S-100 }\end{array}$ & PAC* & NED (4) & IMT & $\begin{array}{c}\text { S/O abscess } 13 \\
\text { months prior to } \\
\text { RP }\end{array}$ \\
\hline
\end{tabular}

Ref: Reference number; UO: urinary obstruction; TUR-P: transurethral resection of the prostate; CP: cystoprostectomy; L/G LMS: low-grade leiomyosarcoma; AFMT: atypical fibromyxoid tumor; PSFMT: pseudosarcomatous fibromyxoid tumor; BPH: benign prostatic hyperplasia; PSL: pseudosarcomatous lesion; CZ: central zone; IMT: inflammatory myofibroblastic tumor; CK: cytokeratin; ALK: anaplastic lymphoma kinase; c-KIT: receptor tyrosine kinase; B\&P: urinary bladder and prostate; FISH: fluorescence in situ hybridization; IHC: immunohistochemistry; AW: alive and well; RP: radical prostatectomy; PAC: prostatic adenocarcinoma; S/O: suggestive of; SPP: suprapubic prostatectomy; TPB: transperineal biopsy; NA: not available; NED: no evidence of disease; DOOD: died of other disease. *Transrectal 12 core needle biopsy taken 2 months prior to radical prostatectomy showed adenocarcinoma in core \#6. "First TUR-P taken 10 months prior to the diagnosis of IMT showed BPH. FFirst TUR-P taken 4 years prior to the diagnosis of IMT showed BPH. 
prostatic IMT were diagnosed as pseudosarcomatous lesions despite the presence of cellular atypia (8) or necrosis (11). Excluding the cases of death from malignant IMT or metastatic disease $(11,13)$, three out of seven cases had good postoperative results with no recurrences and the remaining four cases had recurrence (Table I).

In our case, the fibrous lesion suggesting IMT may have been missed in the previous two transrectal biopsies even though the preoperative CT and MRI findings already showed the presence of a particular lesion. Moreover, the interval between the second transrectal biopsy and the radical operation was 6 weeks, which is relatively short. Considering the probability of IMT not being picked up in the transrectal biopsy from the postoperative specimen despite the IMT growing to $120 \mathrm{~g}$ and occupying most of the prostate axis, we suggest that the lesion was located predominantly in the central and transitional zones but the peripheral zone in which transrectal biopsy was conducted was surrounded by nodular hyperplasia. Although prostatic abscess was not confirmed histologically, considering that liver abscess occurred during long-term diabetes treatment, we suggest that the prostatic abscess arose during the diabetes treatment period, and the lesions may have occurred as a reparative response.

$A L K$ gene alterations were detected by fluorescence in situ hybridization (FISH) in $13(72 \%)$ of the 18 tested cases, including two with injury from previous procedures. Thirteen (72\%) out of the 18 tested cases showed agreement between FISH ALK results and ALK protein results by immunohistochemistry in the IMT of the urinary tract. In addition, five out of the 10 cases found to be ALK-negative by IHC were found to have $A L K$ gene alterations by FISH, while all eight ALK-positive cases by IHC (100\%) had FISH $A L K$ gene alterations. Recurrences were reported to have no association with $A L K$ alterations (11).

In the case presented in this study, ALK expression was not observed through IHC, but a FISH test was not conducted to determine $A L K$ gene alteration. In addition, prostatic adenocarcinoma, which was confirmed in the second transrectal biopsy, was not observed in the radical prostatectomy sample because of the effect of preoperative hormone therapy.

\section{Conclusion}

A large prostatic IMT case with a diameter of $5.2 \mathrm{~cm}$, which was presumed to be associated with the healing process of prostatic abscess, had not been diagnosed in two previous transrectal biopsies. However, it was identified in the samples obtained for radical prostatectomy, which was performed for the treatment of prostatic adenocarcinoma diagnosed from a single core. If a spindle-cell lesion with inflammatory cells is observed in the biopsy sample from a patient with a previous history of injury, IHC must be conducted for $\alpha$-smooth muscle actin, CD10, CD34, desmin, and ALK in considering the possibility of IMT, and a FISH $A L K$ test should be considered if ALK is negative in the IHC examination.

\section{Conflicts of Interest}

The Authors declare no conflicts of interest.

\section{Author's Contributions}

Data Curation: Min Seok Kim. Funding acquisition: Sung-Chul Lim. Methodology: Min Seok Kim, Sung-Chul Lim. Supervision: Sung-Chul Lim. Validation: Sung-Chul Lim. Writing - original draft: Min Seok Kim. Writing - review \& editing: Sung-Chul Lim. Sung-Chul Lim orcid: 0000-0001-6179-691X

\section{Acknowledgements}

This work was supported by research fund from Chosun University, 2017.

\section{References}

1 Roth JA: Reactive pseudosarcomatous response in urinary bladder. Urology 16(6): 635-637, 1980. PMID: 7445316. DOI: 10.1016/0090-4295(80)90578-6

2 Horn LC, Reuter S and Biesold M: Inflammatory pseudotumor of the ureter and the urinary bladder. Pathol Res Pract 193(9): 607-612, 1997. PMID: 9521018. DOI: 10.1016/S0344-0338(97)80037-4

3 Ro JY, el-Naggar AK, Amin MB, Sahin AA, Ordonez NG and Ayala AG: Pseudosarcomatous fibromyxoid tumor of the urinary bladder and prostate: immunohistochemical, ultrastructural, and DNA flow cytometric analyses of nine cases. Hum Pathol 24(11): 1203-1210, 1993. PMID: 7503934. DOI: 10.1016/00468177(93)90217-5

4 Tsuzuki T, Magi-Galluzzi C and Epstein JI: ALK-1 expression in inflammatory myofibroblastic tumor of the urinary bladder. Am J Surg Pathol 28(12): 1609-1614, 2004. PMID: 15577680. DOI: $10.1097 / 00000478-200412000-00009$

5 Debiec-Rychter M, Marynen P, Hagemeijer A and Pauwels P: ALK-ATIC fusion in urinary bladder inflammatory myofibroblastic tumor. Genes Chromosomes Cancer 38(2): 187-190, 2003. PMID: 12939746. DOI: $10.1002 / \mathrm{gcc} .10267$

6 Freeman A, Geddes N, Munson P, Joseph J, Ramani P, Sandison A, Fisher C and Parkinson MC: Anaplastic lymphoma kinase (ALK 1) staining and molecular analysis in inflammatory myofibroblastic tumours of the bladder: A preliminary clinicopathological study of nine cases and review of the literature. Mod Pathol 17(7): 765-771, 2004. PMID: 15105807. DOI: $10.1038 /$ modpathol.3800078

7 Hafiz MA, Toker C and Sutula M: An atypical fibromyxoid tumor of the prostate. Cancer 54(11): 2500-2504, 1984. PMID: 6388807. DOI: 10.1002/1097-0142(19841201)54:11<2500::aidcncr2820541131>3.0.co;2-y

8 Young RH and Scully RE: Pseudosarcomatous lesions of the urinary bladder, prostate gland, and urethra. A report of three cases and review of the literature. Arch Pathol Lab Med 111(4): 354-358, 1987. PMID: 2435260. 
9 Sahin AA, Ro JY, el-Naggar AK, Ordonez NG, Babaian RJ and Ayala AG: Pseudosarcomatous fibromyxoid tumor of the prostate. Am J Clin Pathol 96: 253-258, 1991. DOI: 10.1093/ ajcp/96.2.253

10 Jensen JB, Langkilde NC, Lundbeck F and Marcussen N: Pseudosarcomatous fibromyxoid tumor of the prostate. Scand J Urol Nephrol 37(1): 85-87, 2003. PMID: 12745752. DOI: $10.1080 / 00365590310008776$

11 Montgomery EA, Shuster DD, Burkart AL, Esteban JM, Sgrignoli A, Elwood L, Vaughn DJ, Griffin CA and Epstein JI: Inflammatory myofibroblastic tumors of the urinary tract: A clinicopathologic study of 46 cases, including a malignant example inflammatory fibrosarcoma and a subset associated with high-grade urothelial carcinoma. Am J Surg Pathol 30(12): 1502-1512, 2006. PMID: 17122505. DOI: 10.1097/01.pas.0000213280.35413.1b

12 Zhang HH, Qi F, Zu XB, Xu L, Liu LF and Qi L: Recurrence of inflammatory myofibroblastic tumor in bladder secondary to prostate treated with laparoscopic radical cystectomy. Med Sci Monit 18(8): CS63-66, 2012. PMID: 22847204. DOI: 10.12659/ msm. 883255

13 Liu C, Zhao X, Zhao Z, Lu P, Jin F and Li G: Malignant inflammatory myofibroblastic tumor of the prostate. J Clin Oncol 31(10): e144-147, 2013. PMID: 23401456. DOI: 10.1200/JCO.2012.44.4851

14 Zeng J, He RQ, Mo WG, Peng ZG, Ma J, Zhong JC, Mo CH, Qin MJ and $\mathrm{Hu} \mathrm{XH}$ : Inflammatory myofibroblastic tumor of the prostate after transurethral resection of the prostate with negative expression of anaplastic lymphoma kinase: A case report. Sao Paulo Med J 136(5): 484-487, 2018. PMID: 29898011. DOI: 10.1590/1516-3180.2017.0079070417
15 Tunuguntla H, Mishra A, Jorda $M$ and Gosalbez R: Inflammatory myofibroblastic tumor of the epididymis: Case report and review of the literature. Urology 78(1): 183-185, 2011. PMID: 21146860. DOI: 10.1016/j.urology.2010.09.027

16 Cheuk W, Woo PC, Yuen KY, Yu PH and Chan JK: Intestinal inflammatory pseudotumour with regional lymph node involvement: Identification of a new bacterium as the aetiological agent. J Pathol 192(3): 289-292, 2000. PMID: 11054710. DOI: 10.1002/1096-9896(2000)9999:9999<::AIDPATH767>3.0.CO;2-F

17 Satomi T, Watanabe M, Matsubayashi J, Nagao T and Chiba H: A successfully treated inflammatory myofibroblastic tumor of the mandible with long-term follow-up and review of the literature. Med Mol Morphol 43(3): 185-191, 2010. PMID: 20857269. DOI: 10.1007/s00795-009-0483-6

Received March 13, 2020

Revised April 2, 2020

Accepted April 8, 2020 